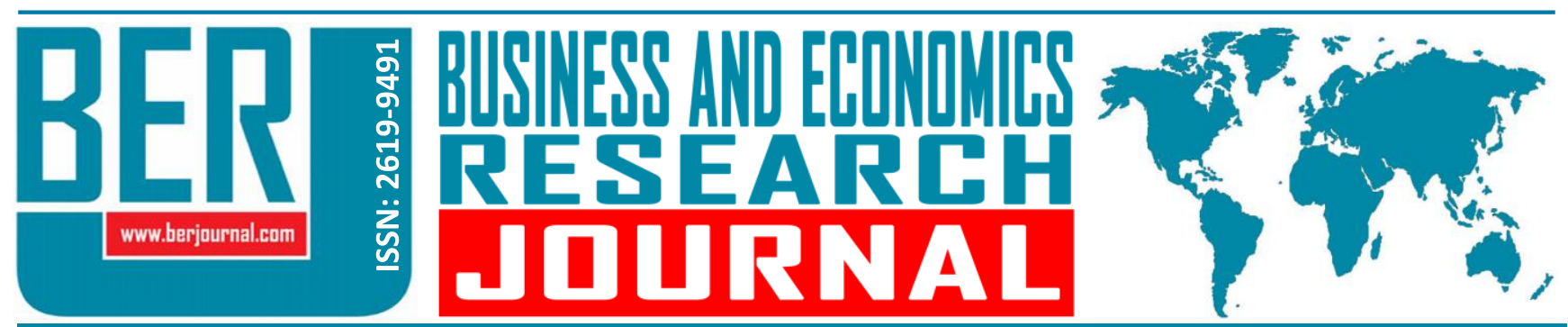

Business and Economics Research Journal Vol. 10, No. 1, 2019, pp. 95-113 doi: 10.20409/berj.2019.157

\title{
A Multi-Criteria Evaluation for Sustainable Supplier Selection Based on Fuzzy Sets*
}

\begin{abstract}
Ahmet Calik
Abstract: It is well known that sustainability strategies have moved further and further up over the past decade due to help companies to improve the effectiveness of their marketplace and perform better in their operations. For companies, sustainability would gain long-term consequences such as getting greater profits and creating their own consumer path. The Triple Bottom Line (TBL) is a key element of the companies to achieve social, environmental, and economic benefits. Supplier's performance directly affects a company's performance not only environmental or economic issues but also sustainable issues. Thus, Sustainable Supplier Selection (SSS) has become the highly relevant topic and many authors and researchers have focused on this subject. This study investigates a hybrid multi-criteria decision making (MCDM) framework based on TBL to determine sustainable suppliers. After construction of hierarchy, the integrated fuzzy MCDM algorithm is implemented. At first, Fuzzy Analytical Hierarchy Process (FAHP) is used for obtaining the weights of the main criteria and related sub-criteria. Then, fuzzy TOPSIS method is applied for ranking the suppliers. Additionally, interval type-2 fuzzy sets (IT2FSs) that express uncertainty better than traditional type-1 fuzzy sets are used for selecting an appropriate supplier. The proposed approach is validated an actual case situation in Konya.
\end{abstract}

Keywords: Interval Type-2 Fuzzy Set, AHP, TOPSIS, Sustainable Supplier Selection

JEL: C44, D70, L62, Q01

$\begin{array}{ll}\text { Received } & : 10 \text { September } 2018 \\ \text { Revised } & : 26 \text { October } 2018 \\ \text { Accepted } & : 23 \text { November } 2018 \\ \text { Type } & : \text { Research }\end{array}$

\section{Introduction}

Importance of sustainable issues have gained much more interest from several customers, researchers and industry experts due to our global future depend on it. Sustainability can be defined by three core elements that are very much linked to one another: economic, environmental and social. Companies should take into consideration sustainable issues to make strategic decisions such as cost savings, risk mitigation, tax incentives, and resource limitations. A company's sustainable performance is not solely dependent on its performance, it is also impressed by the suppliers' performance.

Supplier selection is the most crucial parts of logistics operations due to its direct impact on cash flow and profitability (Banaeian et al., 2018). Suppliers have a critical role for companies in production, delivery, and sustainable issues to increase the quality of products and focus on a specific part of operations. Therefore, the selection of suppliers is an important decision-making problem (Hamdan \& Cheaitou, 2017).

The decision-making process in supplier selection is usually complex and difficult process that the decision makers cannot take a decision with a single criterion. In order to solve these problems, an appropriate approach would be the MCDM methods (Aruldoss et al., 2013). MCDM methods deal with the 
problem of identifying and choosing alternatives according to the criteria that are defined by the decision makers. The main features of an MCDM method include (1) evaluation of criteria, (2) rating of alternatives with respect to criteria, (3) rating of alternatives on the criteria, and (4) a measure for the comparing the criteria (Thokala \& Duenas, 2012).

A company's sustainability performance should be assessed not only by taking into account its own activities but also by taking account of suppliers' performance. Cooperating with suppliers who attach importance to sustainability issues and put into practice them can help to improve the sustainability performance of companies. Even though companies consider specific criteria when assessing suppliers' performance they should consider sustainability for achieving economic profitability and competition.

Integration of sustainability has been increased since the late 1990 s. Companies have begun to feel responsible for controlling their sustainability practices, thus many researchers have attempted to analyse sustainability in logistics management. In sustainable logistics management, SSS is a very difficult issue that suppliers' performance depends on several conflicting criteria.

Many studies have undertaken to improve supplier selection methods in view of the TBL performance of suppliers (Bai \& Sarkis, 2010; Shaw et al., 2012; Shen et al., 2013; Govindan et al., 2013; Wang \& Chan 2013; Kumar et al., 2014; Sarkis \& Dhavale 2015; Mahdiloo et al., 2015; Akman, 2015; Trapp \& Sarkis, 2016). Also, many studies have been implemented using TOPSIS method for supplier selection. Singh et al. (2018) employed FAHP, DEMATEL and TOPSIS methods to handle carbon footprint of suppliers in agri-food sector. Jolai et al. (2011) used TOPSIS method to obtain the ratings of suppliers in their approach. They constructed a multi-objective mixed integer linear programming for order allocation. Banaeian et al. (2018) compared the TOPSIS, VIKOR and GRA methods with fuzzy sets to select green suppliers. Chen et al. (2006) assessed suppliers' performance using fuzzy TOPSIS method in group decision-making process. Awasthi et al. (2010) obtained suppliers enviromental performance score with fuzzy TOPSIS. Önüt et al. (2009) proposed a fuzzy ANP and fuzzy TOPSIS framework for a telecommunication company. Büyüközkan and Çifçi (2012) proposed a hybrid approach consists of DEMATEL, ANP and TOPSIS methods for evaluation of green suppliers. Wang et al. (2009) developed fuzzy hierarchical TOPSIS method. Rodrigues Lima Junior et al. (2014) compared FAHP and TOPSIS methods and showed that Fuzzy TOPSIS method performs better than FAHP method. To address group decision-making problems, the interval type-2 fuzzy TOPSIS method was first presented by Chen and Lee (2010). Deveci et al. (2017) have created a methodology for the destination problem of an airline company which plans to open a route to one of the five airports in North America. The interval type-2 fuzzy TOPSIS methods is used to solve this problem. Cengiz Toklu (2018) proposed an approach to select the most appropriate calibration supplier for an automotive company using the interval type-2 fuzzy TOPSIS method. Baykasoğlu and Gölcük (2017) combined interval type-2 TOPSIS method with the interval type-2 DEMATEL method for the SWOT-based strategy selection problem. Büyüközkan et al. (2016) proposed a group decision framework based on the interval type-2 fuzzy TOPSIS method to evaluate and select the appropriate information management tool. Küçük and Ecer (2008) determined the performance of suppliers and the importance levels of supplier selection factors for a small and medium enterprises that operating in Bayburt with AHP method. Küçük and Ecer (2007) applied fuzzy TOPSIS method to evaluate suppliers in a retail chain store in Erzurum. Özdemir and Yalçın Seçme (2009) used fuzzy TOPSIS method for selecting strategic supplier in a furniture factory has been operating in Turkey.

Some of the recent researches on supplier selection and SSS are described as follows. Azadnia et al. (2015) proposed an integrated approach to SSS with the rule-based weighted fuzzy method. Reuter et al. (2012) formulated a series of hypotheses consisting of six hypotheses based on the orientation of stakeholders for the supplier selection problem. Luthra et al. (2017) used an AHP-VIKOR based integrated approach to prioritize the SSS criteria in an automotive company in India. Song et al. (2017) used the DEMATEL method and rough set theory to propose an integrated approach for an air conditioner. Awasthi et al. (2018) presented an integrated AHP-VIKOR approach, taking risk factors into account for SSS. Kannan (2018) implemented a case study by designing a decision support system based on sustainability performance with the TBL approach. Amindoust (2018) proposed an integrated FIS-DEA model considering resiliency and sustainability issues for supplier selection. Ghadimi et al. (2018) investigated a Multi-Agent Systems taking into account TBL concept for SSS and order allocation. Güner Gören (2018) presented an integrated 
framework consists of DEMATEL, taguchi loss functions and bi-objective optimization. Khan et al. (2018) implemented a hybrid fuzzy shannon entropy and fuzzy inference system methodology for manufacturing company. Kannan et al. (2014) utilized three types of fuzzy TOPSIS methods to rank green suppliers for a Brazilian company. Moreover, three dimensions of sustainability have attracted more attention in recent years (Amindoust et al., 2012; Zimmer et al., 2015; Kannan 2018; Shalke et al., 2018; Vahidi et al., 2018).

Decision-making is the strategic process for selecting a suitable choice among the given alternatives. In this process, MCDM methods help to decision makers to select or order the alternatives according to the multiple criteria. Although in traditional approaches decision makers judgments are represented as exact numbers, human preferences are uncertain and vague. In order to reach more realistic outcomes fuzzy set theory can help decision makers for modelling systems with imprecise input data.

As an extension of fuzzy sets, Zadeh (1975) introduced type-2 fuzzy sets that membership functions of type- 2 fuzzy sets are type- 1 functions. The type- 2 fuzzy sets represent more uncertainty which may model the uncertainties associated with the use of linguistic assessments due to its usefulness in situations where it is difficult to determine the full membership function for a fuzzy set (Mendel et al., 2006). The membership functions of type- 1 fuzzy sets are clear. Type- 1 fuzzy sets cannot provide sufficient explanations because the evaluation criteria are different from each other by decision-makers and personal judgments are different. In such cases, the type-2 fuzzy sets with the membership function type-1 fuzzy sets allow the modelling of real-world fuzziness much more comfortable.

This study aims to compare the performance of fuzzy TOPSIS methods under type- 1 and type-2 fuzzy sets to evaluate suppliers according to TBL approach. For this purpose a real-world case study is demonstrated to select sustainable suppliers. At first, the evaluation criteria based on TBL approach are identified then potential suppliers are evaluated using both type- 1 and type-2 fuzzy TOPSIS. In many cases, type- 1 fuzzy sets are used to deal with vagueness in SSS. But, type- 2 fuzzy sets are expressed the uncertainty and the fuzziness of the real world more than those of type-1 fuzzy sets.

This paper proceeds as follows. Section 2 presents some fundamental about the methods FAHP and Fuzzy TOPSIS. Section 3 presents the results of using the method in a real case application. Finally, concluding remarks are made in Section 4.

\section{The Proposed Framework}

In this study, results that are acquired from a hybrid framework to select the sustainable supplier for a company. After the data collection, the SSS is determined by FAHP and TOPSIS methods. The main steps and the flowchart of the proposed framework are represented in Fig. 1.

Figure 1. The Steps of the Proposed Framework

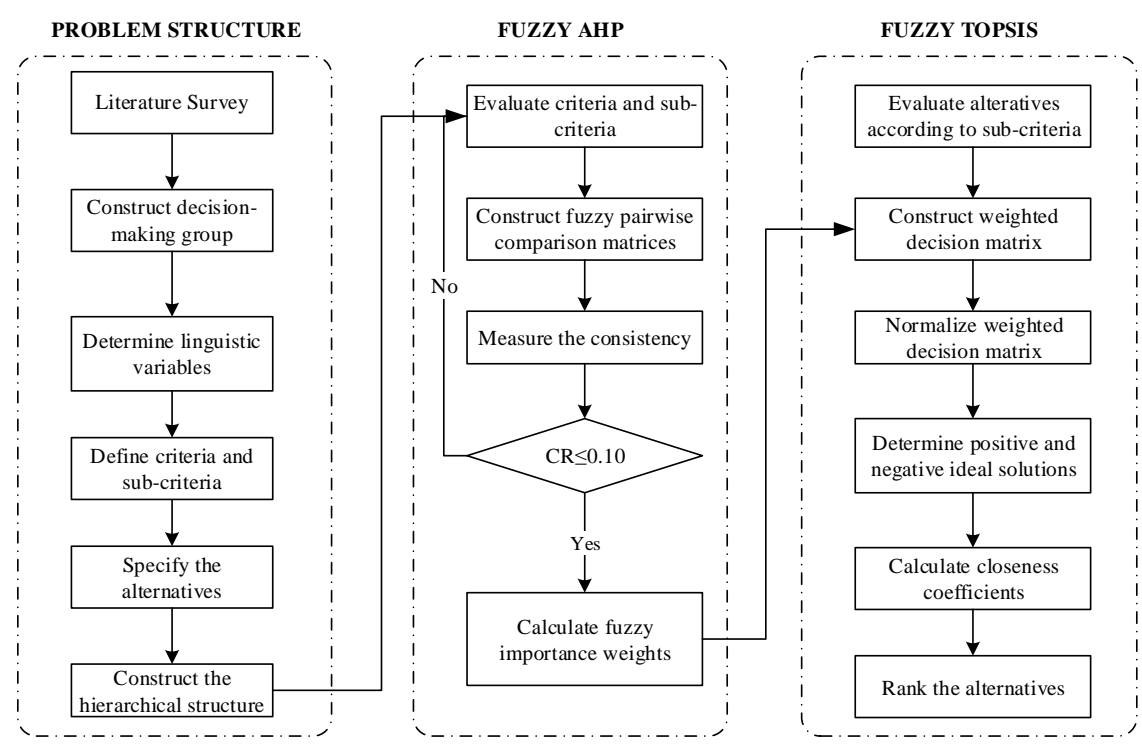




\subsection{Fuzzy Analytical Hierarchy Process (FAHP) Method}

After the first development by Saaty (1980), Buckley (1985) extend the AHP method using triangular fuzzy numbers. In this paper, we utilize the geometric mean method (Buckley, 1985) to obtain criteria weights for the SSS problem. The steps of the method summarized as follows:

Step 1: A fuzzy pair-wise comparison matrix $\left(\tilde{A}=\left[\mathrm{a}_{i j}\right]\right)$ is constructed as:

$$
\tilde{A}=\left[\begin{array}{ccccc}
1 & \cdots & \tilde{a}_{1 j} & \cdots & \tilde{a}_{1 n} \\
\vdots & & \vdots & & \vdots \\
\tilde{a}_{i 1} & \cdots & 1 & \cdots & \tilde{a}_{i n} \\
\vdots & & \vdots & & \vdots \\
\tilde{a}_{n 1} & & \tilde{a}_{n j} & \cdots & 1
\end{array}\right]=\left[\begin{array}{ccccc}
1 & \cdots & \tilde{a}_{1 j} & \cdots & \tilde{a}_{1 n} \\
\vdots & & \vdots & & \vdots \\
1 / \tilde{a}_{i 1} & \cdots & 1 & \cdots & \tilde{a}_{i n} \\
\vdots & & \vdots & & \vdots \\
1 / \tilde{a}_{n 1} & & 1 / \tilde{a}_{n j} & \cdots & 1
\end{array}\right]
$$

where; $\tilde{a}_{i j}=\left(l_{i j}, m_{i j}, u_{i j}\right)$ is a triangular fuzzy number $(i=1,2, \ldots, n, j=1,2, \ldots, m)$.

Step 2: The fuzzy weight matrix is calculated as

$$
\tilde{a}_{i}=\left(\tilde{a}_{i 1} \otimes \tilde{a}_{i 2} \otimes \ldots \otimes \tilde{a}_{i n}\right)^{1 / n}
$$

$m$ is the number of alternatives, $n$ is the number of criteria.

Step 3: The fuzzy weights of each criterion/alternative is calculated by

$$
w_{i}=\tilde{a}_{i} \otimes\left(\tilde{a}_{1} \oplus \tilde{a}_{2} \oplus \ldots \oplus \tilde{a}_{n}\right)^{-1}
$$

where; $\oplus$ is a fuzzy addition operator, and $\otimes$ is a fuzzy multiplication operator (Buckley, 1985).

Step 4: The fuzzy weights $\tilde{w}=\left(w_{l}, w_{m}, w_{u}\right)$ are defuzzified by using the Center of Area method as follows:

$$
w=w_{l}+\left(\frac{\left(w_{u}-w_{l}\right)+\left(w_{m}-w_{l}\right)}{3}\right)=\frac{w_{l}+w_{m}+w_{u}}{3}
$$

\subsection{Fuzzy TOPSIS}

TOPSIS method was originally proposed by Hwang and Yoon in (1981) that considers the distances between alternatives. The main steps of the TOPSIS method are given as follows:

Step 1: Weights of criteria are determined. In this research, Buckley's FAHP method is employed to find the fuzzy criteria weights.

Step 2: Fuzzy decision matrix $\tilde{D}=\left[\tilde{x}_{i j}\right]$ is constructed.

$$
\begin{aligned}
& \begin{array}{llll}
C_{1} & C_{2} & \ldots & C_{n}
\end{array}
\end{aligned}
$$

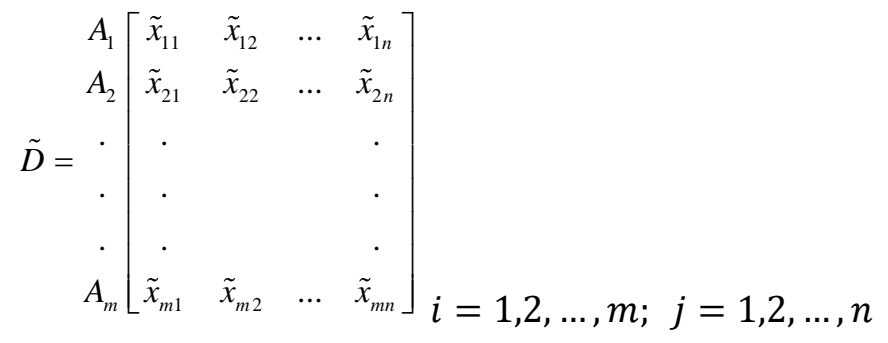

$$
\begin{aligned}
& \widetilde{W}=\left(\widetilde{w}_{1}, \widetilde{w}_{2}, \cdots, \widetilde{w}_{n}\right)
\end{aligned}
$$

$\tilde{x}_{i j}^{K}$ : performance rating of alternative $A_{i}$ with respect to criterion $C_{j}$ evaluated by $K^{t h}$ expert.

Step 3: The Normalized fuzzy decision matrix denoted by $\tilde{R}=\left[\tilde{r}_{i j}\right]$ can be represented as: 


$$
\tilde{r}_{i j}=\left\{\begin{array}{l}
\left(\frac{a_{i j}}{c_{j}^{*}}, \frac{b_{i j}}{c_{j}^{*}}, \frac{c_{i j}}{c_{j}^{*}}\right), c_{j}^{*}=\max _{i} c_{i j}, \text { if } j \in B ; \\
\left(\frac{a_{j}^{-}}{c_{j}^{*}}, \frac{a_{j}^{-}}{c_{j}^{*}}, \frac{a_{j}^{-}}{c_{j}^{*}}\right), a_{j}^{-}=\min _{i} c_{i j}, \text { if } j \in C
\end{array}\right.
$$

where; $B$ denotes benefit criteria and $C$ denotes cost criteria.

Step 4: The weighted normalized fuzzy decision matrix $\tilde{V}=\left[\tilde{v}_{i j}\right]$ is computed as:

$\tilde{v}_{i j}=\tilde{r}_{i j} \otimes \tilde{w}_{j}$

where $w_{j}$ is the weight of the $j$ th criterion.

Step 5: Fuzzy Positive Ideal Solution (FPIS, $A^{*}$ ), and Fuzzy Negative Ideal Solution (FNIS, $A^{-}$) can be calculated as:

$$
\begin{aligned}
& A^{*}=\left[v_{1}^{*}, v_{2}^{*}, \ldots, v_{n}^{*}\right] \\
& A^{-}=\left\lfloor v_{1}^{-}, v_{2}^{-}, \ldots, v_{n}^{-}\right]
\end{aligned}
$$

Step 6: The distances from FPIS and FNIS for each alternative are calculated as:

$$
\begin{aligned}
& d_{i}^{*}=\sum_{j=1}^{n} d\left(\tilde{v}_{i j}, \tilde{v}_{j}^{*}\right), i=1,2, \ldots, m ; j=1,2, \ldots, n \\
& d_{i}^{-}=\sum_{j=1}^{n} d\left(\tilde{v}_{i j}, \tilde{v}_{j}^{-}\right), i=1,2, \ldots, m ; j=1,2, \ldots, n
\end{aligned}
$$

respectively. Where; $d(.,$.$) is the distance between two fuzzy numbers and computed by Vertex method.$

Step 7: The closeness coefficient of each alternative is calculated by:

$$
C C_{i}=\frac{d_{i}^{-}}{d_{i}^{-}+d_{i}^{*}}, i=1,2, \ldots, m
$$

The alternatives are ranked in descending order of the $C C_{i}$ index.

\subsection{Interval Type-2 Fuzzy TOPSIS}

Interval type-2 fuzzy TOPSIS method was developed by Chen and Lee (2010) to solve the MCDM problems based on interval type-2 fuzzy sets (Chen and Lee, 2010). For some definitions of type-2 fuzzy sets and interval type-2 fuzzy sets please see (Kahraman et al., 2014; Çalık \& Paksoy, 2017).

Assume that there is a set $X$ of alternatives, where $X=\left\{x_{1}, x_{2}, \ldots, x_{n}\right\}$ and assume that there is a set $F$ of attributes, where $F=\left\{f_{1}, f_{2}, \ldots, f_{m}\right\}$ and there are $k$ experts $D=\left\{D_{1}, D_{2}, \ldots, D_{k}\right\}$. The set $F$ of attributes can be divided into two sets $F_{1}$ and $F_{2}$, where $F_{1}$ denotes the set of benefit attributes, $F_{2}$ denotes the set of cost attributes, $F_{1} \cap F_{2}=\emptyset$ and $F_{1} \cup F_{2}=F$. Steps of the used interval type-2 fuzzy TOPSIS method given as follows:

Step 1: Construct the decision matrix $Y_{p}$ of the $p$ th decision-maker and construct the average decision matrix $\bar{Y}$, respectively, shown as follows: 


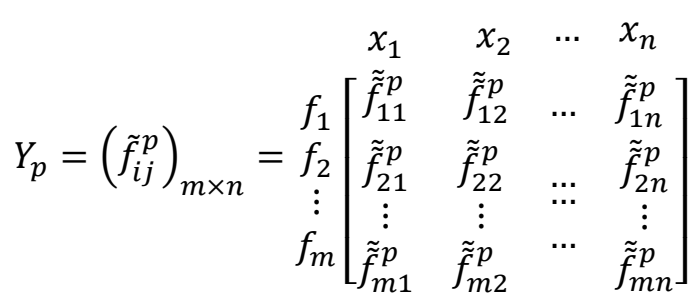

$\bar{Y}=\left(\tilde{f}_{i j}^{p}\right)_{m \times n}$

where $\tilde{\tilde{f}}_{i j}=\left(\frac{\tilde{\tilde{f}}_{i j}^{1} \oplus \tilde{\tilde{f}}_{i j}^{2} \oplus \cdots \oplus \tilde{\tilde{f}}_{i j}^{k}}{k}\right), \tilde{\tilde{f}}_{i j}$ is an IT2FS, $1 \leq i \leq m, 1 \leq j \leq n, 1 \leq p \leq k$, and $k$ denotes the number of decision-makers.

Step 2: Construct the weighting matrix $W_{p}$ of the attributes of the $p$ th decision-maker and construct the average weighting matrix $\bar{W}$, respectively, shown as follows:

$$
\begin{aligned}
& \left.W_{p}=\left(\widetilde{w}_{i}^{p}\right)_{1 \times m}=\begin{array}{cccc}
f_{1} & f_{2} & \cdots & f_{m} \\
\widetilde{w}_{1}^{p} & \widetilde{w}_{2}^{p} & \cdots & \widetilde{w}_{m}^{p}
\end{array}\right] \\
& \bar{W}=\left(\widetilde{\widetilde{w}}_{i}\right)_{1 \times m}
\end{aligned}
$$

where $\widetilde{\widetilde{w}}_{i}=\left(\frac{\widetilde{w}_{i}^{1} \oplus \widetilde{w}_{i}^{2} \oplus \cdots \oplus \widetilde{w}_{i}^{k}}{k}\right), \widetilde{w}_{i}$ is an IT2FS.

Step 3: Construct the weighted decision matrix $\bar{Y}_{w}$

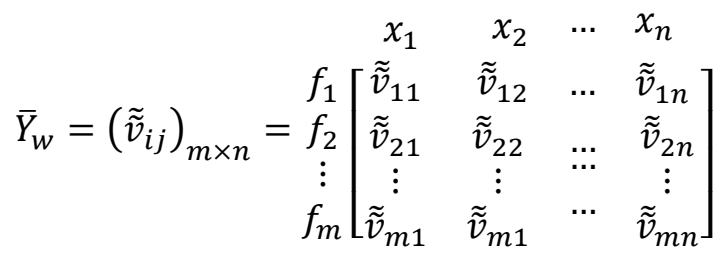

where $\tilde{\tilde{v}}_{i j}=\widetilde{\widetilde{w}}_{i} \otimes \tilde{\tilde{f}}_{i j}$.

Step 4: Based on Eq. (13), calculate the ranking value $\operatorname{Rank}\left(\tilde{\tilde{v}}_{i j}\right)$ of the IT2FS $\tilde{\tilde{v}}_{i j}$ where $1 \leq j \leq n$. Construct the ranking weighted decision matrix

$$
\bar{Y}_{w}^{*}=\left(\operatorname{Rank}\left(\tilde{\tilde{v}}_{i j}\right)\right)_{m \times n}
$$

where $1 \leq i \leq m, 1 \leq j \leq n$.

Definition: The ranking value $\operatorname{Rank}\left(\tilde{\tilde{A}}_{i}\right)$ of the trapezoidal IT2FS $\tilde{\tilde{A}}_{i}$ is defined as follows:

$$
\begin{aligned}
& \operatorname{Rank}\left(\tilde{\tilde{A}}_{i}\right)=M_{1}\left(\tilde{A}_{i}^{U}\right)+M_{1}\left(\tilde{A}_{i}^{L}\right)+M_{2}\left(\tilde{A}_{i}^{U}\right)+M_{2}\left(\tilde{A}_{i}^{L}\right)+M_{3}\left(\tilde{A}_{i}^{U}\right)+M_{3}\left(\tilde{A}_{i}^{L}\right)- \\
& \frac{1}{4}\left(S_{1}\left(\tilde{A}_{i}^{U}\right)+S_{1}\left(\tilde{A}_{i}^{L}\right)+S_{2}\left(\tilde{A}_{i}^{U}\right)+S_{2}\left(\tilde{A}_{i}^{L}\right)+S_{3}\left(\tilde{A}_{i}^{U}\right)+S_{3}\left(\tilde{A}_{i}^{L}\right)+S_{4}\left(\tilde{A}_{i}^{U}\right)+S_{4}\left(\tilde{A}_{i}^{L}\right)\right)+ \\
& H_{1}\left(\tilde{A}_{i}^{U}\right)+H_{1}\left(\tilde{A}_{i}^{L}\right)+H_{2}\left(\tilde{A}_{i}^{U}\right)+H_{2}\left(\tilde{A}_{i}^{L}\right)
\end{aligned}
$$

where $1 \leq i \leq n$. For detailed information please see (Chen \& Lee, 2010; Erdoğan \& Kaya, 2016).

Step 5: Determine the positive ideal solution $x^{+}=\left\{\tilde{v}_{1}^{+}, \tilde{v}_{2}^{+}, \cdots, \tilde{v}_{m}^{+}\right\}$and the negative-ideal solution $x^{-}=$ $\left\{\tilde{v}_{1}^{-}, \tilde{v}_{2}^{-}, \cdots, \tilde{v}_{m}^{-}\right\}$, where 


$$
\tilde{v}_{i}^{+}= \begin{cases}\max _{1 \leq j \leq n}\left\{\operatorname{Rank}\left(\tilde{\tilde{v}}_{i j}\right)\right\}, & \text { if } f_{i} \in F_{1} \\ \min _{1 \leq j \leq n}\left\{\operatorname{Rank}\left(\tilde{\tilde{v}}_{i j}\right)\right\}, & \text { if } f_{i} \in F_{2}\end{cases}
$$

and

$$
\tilde{v}_{i}^{-}= \begin{cases}\min _{1 \leq j \leq n}\left\{\operatorname{Rank}\left(\tilde{\tilde{v}}_{i j}\right)\right\}, & \text { if } f_{i} \in F_{1} \\ \max _{1 \leq j \leq n}\left\{\operatorname{Rank}\left(\tilde{\tilde{v}}_{i j}\right)\right\}, & \text { if } f_{i} \in F_{2}\end{cases}
$$

Step 6: Calculate the distance $d^{+}\left(x_{j}\right)$ between each alternative $x_{j}$ and the positive ideal solution $x^{+}$, shown as follows

$$
d^{+}\left(x_{j}\right)=\sqrt{\sum_{i=1}^{m}\left(\operatorname{Rank}\left(\tilde{\tilde{v}}_{i j}\right)-\tilde{v}_{i}^{+}\right)^{2}}
$$

where $1 \leq j \leq n$. Calculate the distance $d^{-}\left(x_{j}\right)$ between each alternative $x_{j}$ and the negatif ideal solution $x^{-}$, shown as follows

$$
d^{-}\left(x_{j}\right)=\sqrt{\sum_{i=1}^{m}\left(\operatorname{Rank}\left(\tilde{\tilde{v}}_{i j}\right)-\tilde{v}_{i}^{-}\right)^{2}}
$$

Step 7: Calculate the relative degree of closeness $C\left(x_{j}\right)$ of $x_{j}$ with respect to the positive ideal solution $x^{+}$, shown as follows

$$
C\left(x_{j}\right)=\frac{d^{-}\left(x_{j}\right)}{d^{-}\left(x_{j}\right)+d^{+}\left(x_{j}\right)}
$$

where $1 \leq j \leq n$.

Step 8: Rank the values of $C\left(x_{j}\right)$ in a descending order, where $1 \leq j \leq n$. Select the alternative $x_{j}$ with the highest $C\left(x_{j}\right)$.

\section{Application of the Proposed Framework}

The proposed framework is illustrated in a case study. In the case study, SSS is implemented in the procurement and logistics department of an automotive company, established in 1976 in Konya, Turkey. It has more than 40 years of experience in the sector and total exports of the firm products have been transported to several countries. Therefore, the company has been started to improve its supplier selection practices considering sustainable factors. From this viewpoint, a case study of Turkish automotive company is illustrated for considering the validity of the proposed methodology.

In the case study, SSS criteria concerning economic, environmental and social criteria are selected through a detailed literature search and discussion with a committee who have rich knowledge and experience in sustainability. The committee including CEO (D1), the chief purchasing and operations manager (D2) and the chief logistics officer (D3) have been determined three main criteria and nine sub-criteria and four appropriate suppliers. Figure 2 represents the hierarchical structure of the SSS problem. A brief definition of criteria is represented in Table 1. 
Table 1. Criteria Definition of SSS Problem

\begin{tabular}{|c|c|c|}
\hline & Criteria & Definition \\
\hline \multirow{3}{*}{$\begin{array}{l}\text { Economic Criteria } \\
\qquad(\mathrm{EC})\end{array}$} & Cost (C) & $\begin{array}{l}\text { The cost includes the unit price of raw materials, parts and/or } \\
\text { products as well as transportation cost, logistics costs, } \\
\text { maintenance costs etc. }\end{array}$ \\
\hline & Quality (Q) & $\begin{array}{l}\text { In order to reach high standards, companies should take into } \\
\text { consideration the level of quality products that it can directly } \\
\text { affect the quality of the finished products. }\end{array}$ \\
\hline & On time delivery (OTD) & $\begin{array}{l}\text { Companies require their suppliers to be finished their goods } \\
\text { in a certain time period so that they can reduce inventory, } \\
\text { waste, and overcapacity. }\end{array}$ \\
\hline \multirow{3}{*}{$\begin{array}{l}\text { Environmental } \\
\text { Criteria (EN) }\end{array}$} & $\begin{array}{l}\text { Carbon dioxide emission } \\
\left(\mathrm{CO}_{2}\right)\end{array}$ & $\begin{array}{l}\text { Managing the carbon dioxide emission of products is an } \\
\text { important factor to decrease climate change effects. }\end{array}$ \\
\hline & Pollution Production (PP) & $\begin{array}{l}\text { The use of detrimental substances should be restricted to } \\
\text { reduce pollution production. Pollution production is an } \\
\text { important criterion that must be taken in order to select } \\
\text { suitable suppliers. }\end{array}$ \\
\hline & $\begin{array}{l}\text { Environmental } \\
\text { systems (EMS) }\end{array}$ & $\begin{array}{l}\text { An environmental management system is a set of processes } \\
\text { and practices that enable an organization to reduce } \\
\text { environmental impact and increase operational efficiency. }\end{array}$ \\
\hline \multirow{2}{*}{ Social Criteria (SO) } & $\begin{array}{l}\text { Occupational Health and } \\
\text { Safety (OHS) }\end{array}$ & $\begin{array}{l}\text { OHS explains the prevention among workers of adverse } \\
\text { effects on health caused by their working conditions }\end{array}$ \\
\hline & $\begin{array}{l}\text { CSR Projects and Campaigns } \\
\text { (CSR) }\end{array}$ & $\begin{array}{l}\text { A company's performance is directly affected by suppliers' } \\
\text { image, a supplier's adverse CSR performance might damage } \\
\text { the company's reputation. }\end{array}$ \\
\hline
\end{tabular}

Figure 2. The Hierarchical Structure of the SSS Problem

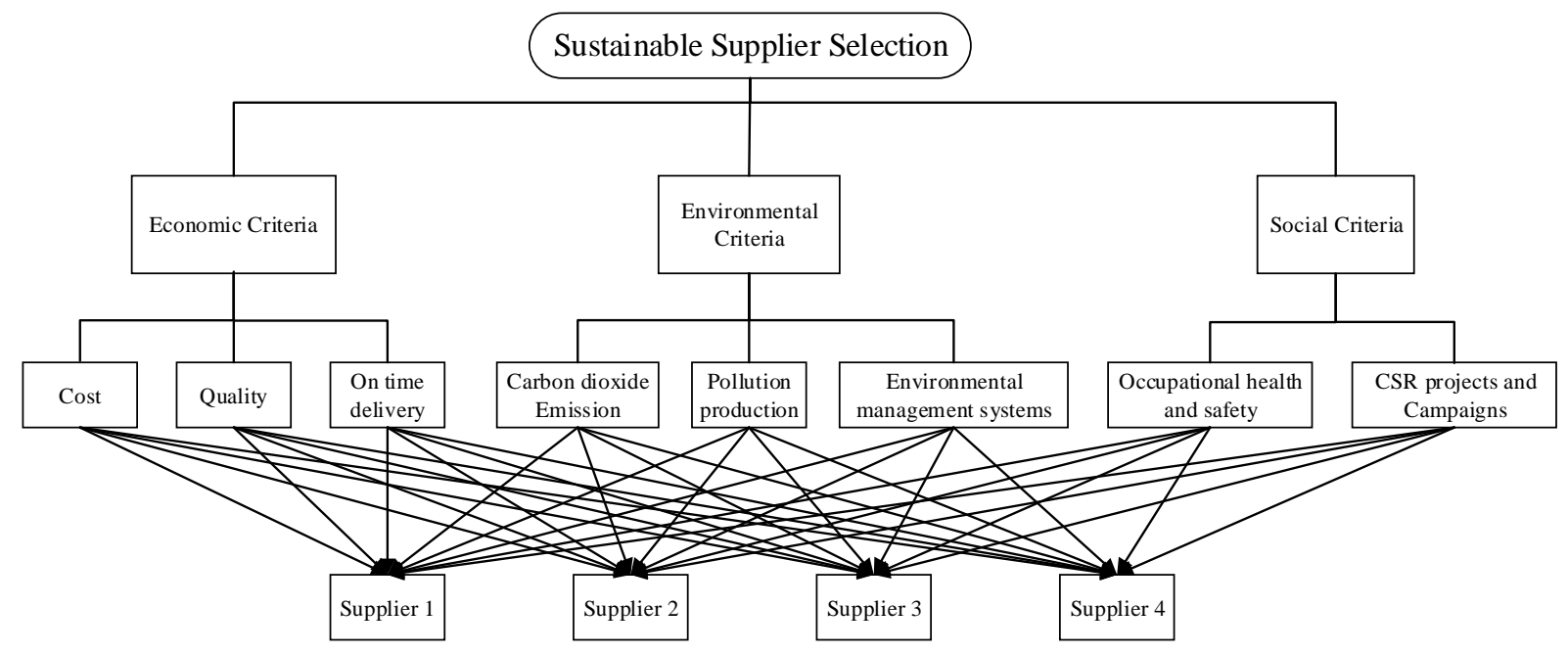




\subsection{FAHP Method for Determining Criteria Weights}

The three managers express their opinions to assess the importance of the criteria using the linguistic variables shown in Table 2. The assessment of each managers' main criteria and sub-criteria are given in Tables 3-6. The geometric mean method is used to aggregate their opinions and aggregated fuzzy pair-wise comparison matrix is presented in Table 7. The importance of criteria are given in Table 8.

Table 2. Linguistic Variables for Pairwise Comparisons of Each Criterion (Lin, 2010)

\begin{tabular}{lcc}
\hline Linguistic variables & $\begin{array}{c}\text { Intensity of } \\
\text { importance }\end{array}$ & $\begin{array}{c}\text { Triangular fuzzy } \\
\text { scale }\end{array}$ \\
\hline Equally important & 1 & $(1,1,1)$ \\
Intermediate & 2 & $(1,2,3)$ \\
Weakly more important & 3 & $(2,3,4)$ \\
Intermediate & 4 & $(3,4,5)$ \\
Strongly more important & 5 & $(4,5,6)$ \\
Intermediate & 6 & $(5,6,7)$ \\
Very strongly more important & 7 & $(6,7,8)$ \\
Intermediate & 8 & $(7,8,9)$ \\
Absolutely more important & 9 & $(9,9,9)$ \\
\hline
\end{tabular}

The same procedure is implemented for sub-criteria and relative importance weights of the subcriteria are summarized in Table 9.

Table 3. The Assessments of Decision Makers for Main Criteria

\begin{tabular}{cccccccccc}
\hline & \multicolumn{3}{c}{ D1 } & \multicolumn{1}{c}{ D2 } & \multicolumn{3}{c}{ D3 } \\
\hline & EC & EN & SO & EC & EN & SO & EC & EN & SO \\
\hline EC & $(1,1,1)$ & $(2,3,4)$ & $(4,5,6)$ & $(1,1,1)$ & $(4,5,6)$ & $(2,3,4)$ & $(1,1,1)$ & $(2,3,4)$ & $(2,3,4)$ \\
EN & & $(1,1,1)$ & $(2,3,4)$ & & $(1,1,1)$ & $(1,2,3)$ & & $(1,1,1)$ & $(4,5,6)$ \\
SO & & & $(1,1,1)$ & & & $(1,1,1)$ & & & $(1,1,1)$ \\
\hline
\end{tabular}

Table 4. The Assessments of Decision Makers for Economic Criteria

\begin{tabular}{cccccccccc}
\hline & & D1 & \multicolumn{9}{c}{ D2 } & \multicolumn{4}{c}{ D3 } \\
\hline & C & Q & OTD & C & Q & OTD & C & Q & OTD \\
\hline C & $(1,1,1)$ & $(4,5,6)$ & $(6,7,8)$ & $(1,1,1)$ & $(4,5,6)$ & $(5,6,7)$ & $(1,1,1)$ & $(1,2,3)$ & $(1 / 4,1 / 3,1 / 2)$ \\
Q & & $(1,1,1)$ & $(2,3,4)$ & & $(1,1,1)$ & $(1,2,3)$ & & $(1,1,1)$ & $(1 / 4,1 / 3,1 / 2)$ \\
OTD & & & $(1,1,1)$ & & & $(1,1,1)$ & & & $(1,1,1)$ \\
\hline
\end{tabular}

Table 5. The Assessments of Decision Makers for Environmental Criteria

\begin{tabular}{cccccccccc}
\hline & \multicolumn{2}{c}{$\mathrm{D} 1$} & \multicolumn{1}{c}{$\mathrm{D} 2$} & \multicolumn{2}{c}{$\mathrm{D} 3$} \\
\hline & $\mathrm{CO}_{2}$ & $\mathrm{PP}$ & $\mathrm{EMS}$ & $\mathrm{CO}_{2}$ & $\mathrm{PP}$ & $\mathrm{EMS}$ & $\mathrm{CO}_{2}$ & $\mathrm{PP}$ & EMS \\
\hline $\mathrm{CO}_{2}$ & $(1,1,1)$ & $(2,3,4)$ & $(1 / 4,1 / 3,1 / 2)$ & $(1,1,1)$ & $(4,5,6)$ & $(4,5,6)$ & $(1,1,1)$ & $(1 / 6,1 / 5,1 / 4)$ & $(2,3,4)$ \\
$\mathrm{PP}$ & & $(1,1,1)$ & $(1 / 6,1 / 5,1 / 4)$ & & $(1,1,1)$ & $(1,2,3)$ & & $(1,1,1)$ & $(6,7,8)$ \\
$\mathrm{EMS}$ & & & $(1,1,1)$ & & & $(1,1,1)$ & & & $(1,1,1)$ \\
\hline
\end{tabular}


A Multi-Criteria Evaluation for Sustainable Supplier Selection Based on Fuzzy Sets

Table 6. The Assessments of Decision Makers for Social Criteria

\begin{tabular}{ccccccc}
\hline \multicolumn{2}{c}{ D1 } & \multicolumn{2}{c}{ D2 } & D3 \\
\hline & OHS & CSR & OHS & CSR & OHS & SO \\
\hline OHS & $(1,1,1)$ & $(2,3,4)$ & $(1,1,1)$ & $(4,5,6)$ & CSR & $(1 / 6,1 / 5,1 / 4)$ \\
CSR & & $(1,1,1)$ & & $(1,1,1)$ & & $(1,1,1)$ \\
\hline
\end{tabular}

Table 7. Aggregated Assessments of Managers' for Main Criteria

\begin{tabular}{cccc}
\hline & EC & EN & SO \\
\hline EC & $(1,1,1)$ & $(2.520,3.557,4.579)$ & $(2.520,3.557,4.579)$ \\
EN & $(0.218,0.281,0.397)$ & $(1,1,1)$ & $(2,3.107,4.160)$ \\
SO & $(0.218,0.281,0.397)$ & $(0.240,0.322,0.5)$ & $(1,1,1)$ \\
\hline
\end{tabular}

Table 8. The Fuzzy Weights for the Main Criteria

\begin{tabular}{ll}
\hline EC & $(0.409,0.624,0.924)$ \\
EN & $(0.168,0.256,0.396)$ \\
SO & $(0.083,0.120,0.195)$ \\
\hline
\end{tabular}

Table 9. The fuzzy weights for sub-criteria

\begin{tabular}{ccc}
\hline & & Fuzzy Weights \\
\hline \multirow{3}{*}{ EC } & $\mathrm{C}$ & $(0.406,0.598,0.864)$ \\
& $\mathrm{Q}$ & $(0.131,0.202,0.318)$ \\
& OTD & $(0.135,0.200,0.306)$ \\
\hline \multirow{2}{*}{ EN } & $\mathrm{CO}_{2}$ & $(0.300,0.473,0.752)$ \\
& PP & $(0.189,0.314,0.511)$ \\
& EMS & $(0.133,0.213,0.343)$ \\
\hline \multirow{2}{*}{ SO } & OHS & $(0.462,0.662,0.961)$ \\
& CSR & $(0.231,0.338,0.481)$ \\
\hline
\end{tabular}

\subsection{Fuzzy TOPSIS Method for Ranking Sustainable Suppliers}

The three DMs express their assessments using the linguistic variables shown in Table 10 with respect to each sub-criterion. Table 11 shows the assessment information provided by the three managers. It is aimed to determine the rank of the best suppliers by using fuzzy TOPSIS method and results of the method are given in Tables 12-16. All the calculations were conducted using Ms. Excel.

Table 10. Linguistic Variable for Assessment of Sub-Criteria

\begin{tabular}{cc}
\hline Linguistic variable & Fuzzy Numbers \\
\hline Very poor (VP) & $(0,1,3)$ \\
Poor (P) & $(1,3,5)$ \\
Fair (F) & $(3,5,7)$ \\
Good (G) & $(5,7,9)$ \\
Very good (VG) & $(7,9,10)$ \\
\hline
\end{tabular}


A. Calik

Table 11. Evaluation of Suppliers of Managers Related with Sub-Criteria

\begin{tabular}{|c|c|c|c|c|c|}
\hline & & \multirow{2}{*}{ Suppliers } & \multicolumn{3}{|c|}{ Managers } \\
\hline \multirow{13}{*}{ EC } & & & M1 & M2 & M3 \\
\hline & \multirow{4}{*}{ C } & S1 & $\mathrm{F}$ & G & G \\
\hline & & S2 & $\mathrm{F}$ & $\mathrm{F}$ & $\mathrm{P}$ \\
\hline & & S3 & $\mathrm{F}$ & G & $\mathrm{F}$ \\
\hline & & S4 & VG & VG & G \\
\hline & \multirow{4}{*}{$Q$} & S1 & $\mathrm{F}$ & $\mathrm{F}$ & $\mathrm{P}$ \\
\hline & & S2 & G & G & VG \\
\hline & & S3 & $P$ & VP & $\mathrm{P}$ \\
\hline & & S4 & VG & G & VG \\
\hline & \multirow{4}{*}{ OTD } & S1 & $\mathrm{F}$ & $\mathrm{F}$ & G \\
\hline & & S2 & G & G & $\mathrm{F}$ \\
\hline & & S3 & $P$ & $P$ & $\mathrm{~F}$ \\
\hline & & S4 & VG & G & VG \\
\hline \multirow{12}{*}{ EN } & \multirow{4}{*}{$\mathrm{CO} 2$} & S1 & $P$ & $P$ & $\mathrm{P}$ \\
\hline & & S2 & $\mathrm{F}$ & $\mathrm{F}$ & G \\
\hline & & S3 & VP & VP & $P$ \\
\hline & & S4 & VG & VG & G \\
\hline & \multirow{4}{*}{ PP } & S1 & $P$ & $\mathrm{~F}$ & $\mathrm{P}$ \\
\hline & & S2 & $\mathrm{F}$ & $\mathrm{F}$ & G \\
\hline & & S3 & VP & VP & $\mathrm{P}$ \\
\hline & & S4 & VG & VG & G \\
\hline & \multirow{4}{*}{ EMS } & S1 & $\mathrm{F}$ & $\mathrm{F}$ & $\mathrm{F}$ \\
\hline & & S2 & G & G & G \\
\hline & & S3 & $P$ & VP & $\mathrm{P}$ \\
\hline & & S4 & G & VG & G \\
\hline \multirow{8}{*}{ so } & \multirow{4}{*}{$\mathrm{OHS}$} & S1 & VP & $P$ & $\mathrm{P}$ \\
\hline & & S2 & $P$ & $\mathrm{~F}$ & $\mathrm{~F}$ \\
\hline & & S3 & VP & $P$ & $P$ \\
\hline & & S4 & G & G & VG \\
\hline & \multirow{4}{*}{ CSR } & S1 & VP & $P$ & $P$ \\
\hline & & S2 & $\mathrm{F}$ & $P$ & $\mathrm{~F}$ \\
\hline & & S3 & VP & $P$ & VP \\
\hline & & S4 & G & VG & G \\
\hline
\end{tabular}




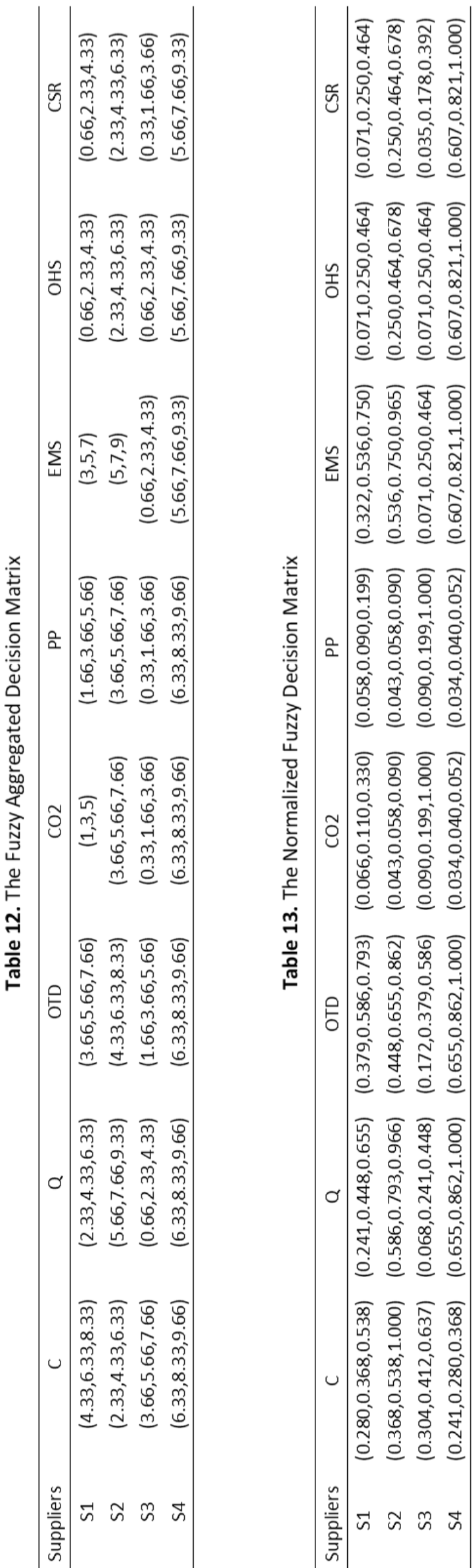




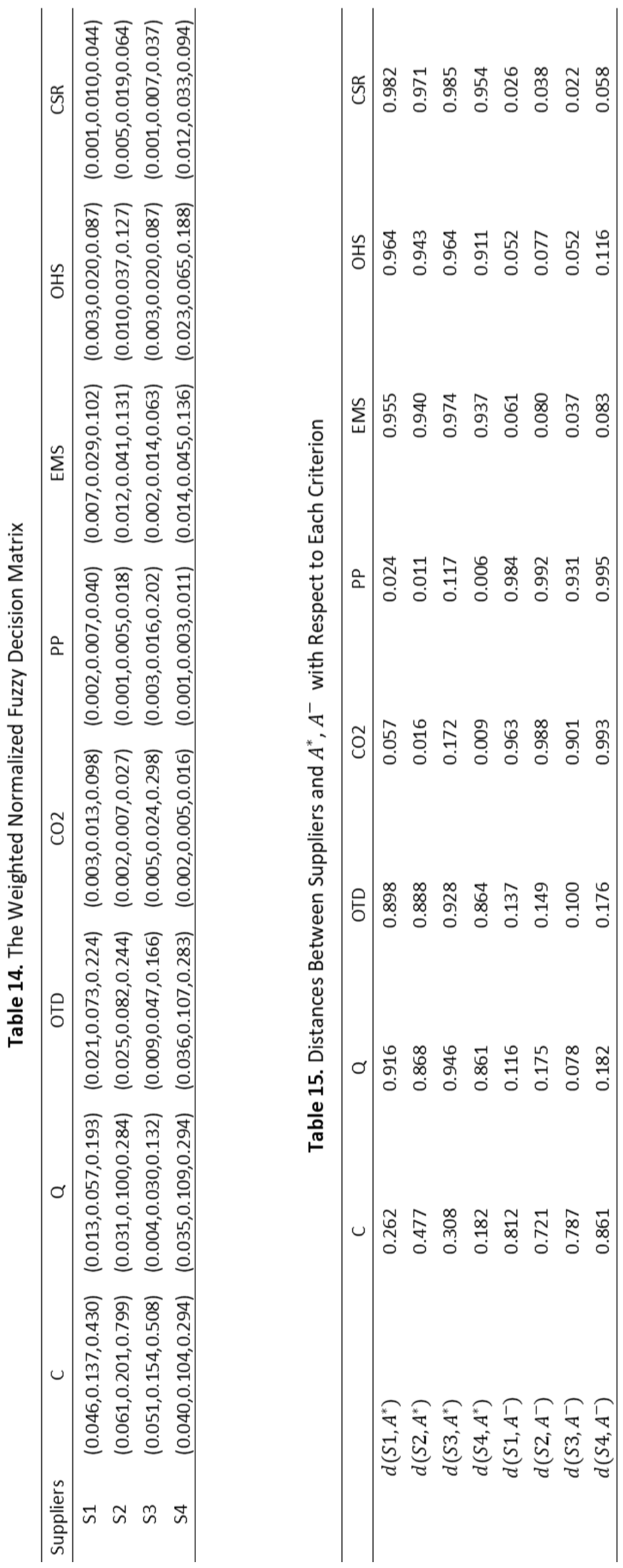


Table 16. Computations of $d^{+}, d^{-}$and $C C_{i}$

\begin{tabular}{ccccc}
\hline Suppliers & $d^{+}$ & $d^{-}$ & $C C_{i}$ & Rank \\
\hline S1 & 5.057 & 3.150 & 0.384 & 3 \\
S2 & 5.114 & 3.220 & 0.386 & 2 \\
S3 & 5.396 & 2.908 & 0.350 & 4 \\
S4 & 4.724 & 3.463 & 0.423 & 1 \\
\hline
\end{tabular}

Comparative ranking of the alternative suppliers based on the closeness coefficients is obtained. Under the light of the results, Supplier 4 is the best sustainable supplier because of the shortest distance to the ideal solution.

\subsection{Interval Type-2 Fuzzy TOPSIS method}

Extension of the proposed framework also is investigated by interval type-2 fuzzy TOPSIS method. The weights of criteria determined by Eq. (9) to perform interval type-2 fuzzy TOPSIS method. The DMs use a seven-point scale that is taken from (Chen \& Lee, 2010) to obtain the weights of the main criteria and subcriteria and evaluate the suppliers, respectively. Table 17 indicates the linguistic evaluations of the main criteria and sub-criteria and Table 18 shows the calculation results of criteria weights.

Table 17. Linguistic Evaluations of the Main Criteria and Sub-Criteria

\begin{tabular}{cccc}
\hline \multicolumn{3}{c}{ Decision makers } \\
\hline Criteria & $\mathrm{D} 1$ & $\mathrm{D} 2$ & $\mathrm{D} 3$ \\
\hline $\mathrm{EC}$ & $\mathrm{H}$ & $\mathrm{MH}$ & $\mathrm{M}$ \\
$\mathrm{EN}$ & $\mathrm{MH}$ & $\mathrm{MH}$ & $\mathrm{ML}$ \\
$\mathrm{SO}$ & $\mathrm{M}$ & $\mathrm{ML}$ & $\mathrm{ML}$ \\
$\mathrm{C}$ & $\mathrm{H}$ & $\mathrm{MH}$ & $\mathrm{MH}$ \\
$\mathrm{Q}$ & $\mathrm{MH}$ & $\mathrm{M}$ & $\mathrm{ML}$ \\
OTD & $\mathrm{ML}$ & $\mathrm{ML}$ & $\mathrm{ML}$ \\
$\mathrm{CO}_{2}$ & $\mathrm{M}$ & $\mathrm{MH}$ & $\mathrm{M}$ \\
$\mathrm{PP}$ & $\mathrm{M}$ & $\mathrm{M}$ & $\mathrm{ML}$ \\
$\mathrm{EMS}$ & $\mathrm{L}$ & $\mathrm{ML}$ & $\mathrm{ML}$ \\
$\mathrm{OHS}$ & $\mathrm{MH}$ & $\mathrm{M}$ & $\mathrm{ML}$ \\
$\mathrm{CSR}$ & $\mathrm{M}$ & $\mathrm{ML}$ & $\mathrm{ML}$ \\
\hline
\end{tabular}

Based on Table 17 and Eq. (9), Table 18 represents the interval type-2 weights of criteria. These results are used in interval type-2 fuzzy TOPSIS method then the ranking values are obtained. Evaluation of the suppliers with respect to criteria is determined by using rating scale (Chen \& Lee, 2010). Evaluation of suppliers that given in Table 11 is used to obtain decision matrix. The decision matrix for the suppliers is computed by using Eqs. (7) and (8) in Table 19. The weighted decision matrix is constructed with Eq. (11) and shown in Table 20. The distances from positive ideal and negative ideal solutions can be computed using Eqs. (16) and (17), presented in Table 21. Finally, the closeness coefficient of each alternative is computed by Eq. (18) and given in Table 21. For more details about interval type-2 fuzzy TOPSIS calculation examples, please see (Chen \& Lee, 2010; Erdoğan \& Kaya, 2016; Büyüközkan et al., 2016). 


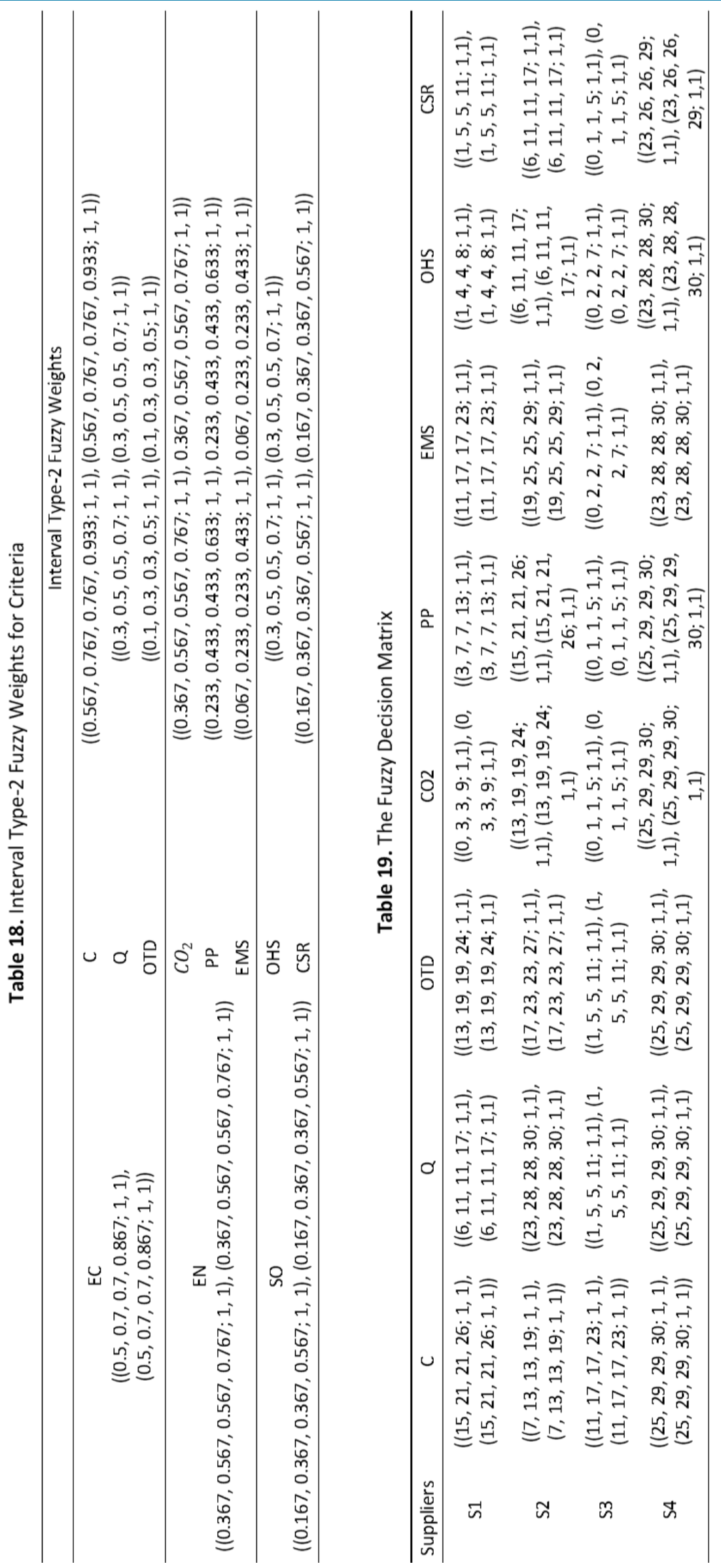




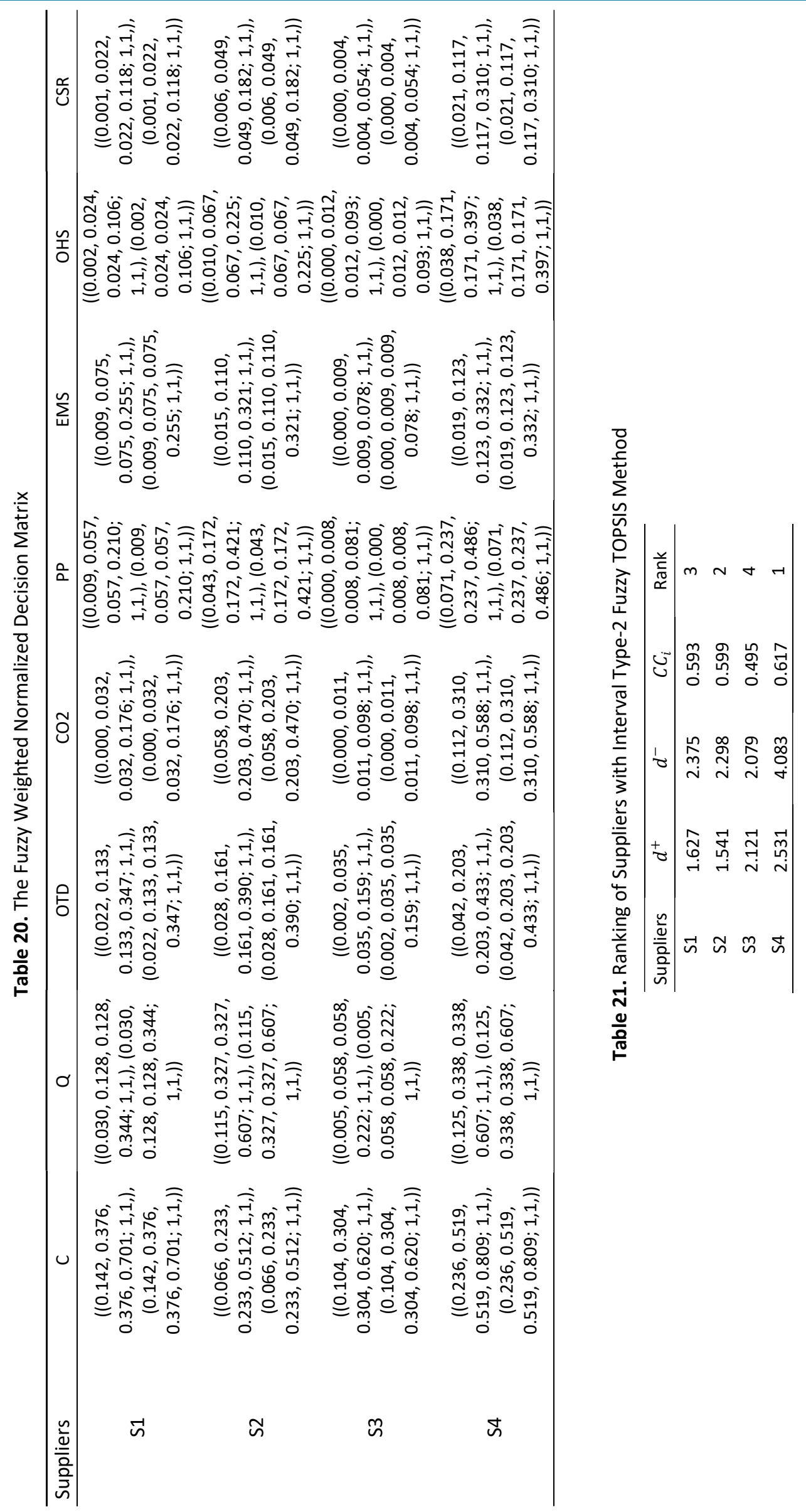


It can be seen in Table 21, the ranking of suppliers are obtained at the same order (Supplier 4-Supplier 2-Supplier 1-Supplier 3) for the company. Fuzzy TOPSIS method is useful in solving problems that require linguistic uncertainty and group decision. Decision makers evaluate the significance of decision criteria and each alternative according to these decision criteria. The best alternative is chosen that has the closest distance to the positive ideal solution and the farthest distance the negative ideal solution. As a result of evaluations made by decision makers according to their criteria, the best supplier is obtained as Supplier 4 .

\section{Conclusion}

Incorporation of sustainability into supply chain management has attracted the greatest interest from practitioners and researchers. Although in the past decade, sustainability has become an important goal for companies, non-profit-making organizations, and governments, it is difficult to measure the extent to which an institution is sustainable or a sustainable growth line. Analysing sustainability is always subjective, and thus the decision-making models are crucial in this environment. In the practice of sustainability, TBL principles expand the traditional accounting by considering environmental and social impacts. This research presents an integrated fuzzy multi-criteria evaluation fremework SSS in the context of TBL. Firstly, criteria weights are evaluated by using FAHP method. Based on the weights of sustainability criteria, we observed that economic criteria are the most effective factor the considered factors. Then, fuzzy TOPSIS method is performed to rank potential suppliers both type-1 fuzzy sets and type-2 fuzzy sets considering economic, environmental and social main criteria and their sub-criteria. Performance of the fuzzy sets was compared for the integrated method. Interval type-2 fuzzy sets are most noteworthy because the mathematics required for such clusters is much simpler than the mathematics required for a general type- 2 fuzzy sets. Additionally, interval type-2 fuzzy sets allow to come from the linguistic uncertainties in human thinking style and capture the vagueness of this style rather than type-1 fuzzy sets. This methodology may be used together with another multi-criteria methods such as AHP-ELECTRE, or AHP-VIKOR. Also, different fuzzy MCDM methods such as interval hesitant or intuitionistic fuzzy sets can be used in the future.

\section{End Notes}

* This paper is an extension of a conference paper entitled A Triple Bottom Line Approach for Sustainable Supplier Selection by Using Fuzzy Multi-Criteria Evaluation that published in Conference Proceedings of $11^{\text {th }}$ International Conferences on in istanbul.

\section{References}

Akman, G. (2015). Evaluating suppliers to include green supplier development programs via fuzzy c-means and VIKOR methods. Computers \& Industrial Engineering, 86, 69-82.

Amindoust, A. (2018). A resilient-sustainable based supplier selection model using a hybrid intelligent method. Computers \& Industrial Engineering, 126, 122-135.

Amindoust, A., Ahmed, S., Saghafinia, A., \& Bahreininejad, A. (2012). Sustainable supplier selection: A ranking model based on fuzzy inference system. Applied Soft Computing, 12, 1668-1677.

Aruldoss, M., Lakshmi, T. M., \& Venkatesan, V. P. (2013). A survey on multi criteria decision making methods and its applications. American Journal of Information Systems, 1(1), 31-43.

Awasthi, A., Chauhan, S. S., \& Goyal, S. K. (2010). A fuzzy multi criteria approach for evaluating environmental performance of suppliers. International Journal of Production Economics, 126, 370-378.

Awasthi, A., Govindan, K., \& Gold, S. (2018). Multi-tier sustainable global supplier selection using a fuzzy AHP-VIKOR based approach. International Journal of Production Economics, 195, 106-117.

Azadnia, A. H., Saman, M. Z. M., \& Wong, K. Y. (2015). Sustainable supplier selection and order lot-sizing: An integrated multi-objective decision-making process. International Journal of Production Research, 53, 383-408.

Bai, C., \& Sarkis, J. (2010). Green supplier development: Analytical evaluation using rough set theory. Journal of Cleaner Production, 18(12), 1200-1210. 
Banaeian, N., Mobli, H., Fahimnia, B., Nielsen, I. E., \& Omid, M. (2018). Green supplier selection using fuzzy group decision making methods: A case study from agri-food industry. Computers \& Operations Research, 89, 337-347.

Baykasoğlu, A., \& Gölcük, í. (2017). Development of an interval type-2 fuzzy sets based hierarchical MADM model by combining DEMATEL and TOPSIS. Expert Systems with Applications, 70, 37-51.

Buckley, J. J. (1985). Fuzzy hierarchical analysis. Fuzzy Sets and Systems, 17(3), 233-247.

Büyüközkan, G., \& Çifçi, G. (2012). A novel hybrid MCDM approach based on fuzzy DEMATEL, fuzzy ANP and fuzzy TOPSIS to evaluate green suppliers. Expert Systems with Applications, 39, 3000-3011.

Büyüközkan, G., Parlak, I. B., \& Tolga, A. C. (2016). Evaluation of knowledge management tools by using an interval type2 fuzzy TOPSIS method. International Journal of Computational Intelligence Systems, 9(5), 812-826.

Çalık, A., \& Paksoy, T. (2017). Third-party reverse logistics (3PTL) company selection with interval type-2 fuzzy ahp. Selçuk Üniversitesi Sosyal Bilimler Meslek Yüksekokulu Dergisi, 20(1), 52-67.

Cengiz Toklu, M. (2018). Interval type-2 fuzzy TOPSIS method for calibration supplier selection problem: A case study in an automotive company. Arabian Journal of Geosciences, 11, 341.

Chen, C. T., Lin, C. T., \& Huang, S. F. (2006). A fuzzy approach for supplier evaluation and selection in supply chain management. International Journal of Production Economics, 102(2), 289-301.

Chen, S. M., \& Lee, L. W. (2010). Fuzzy multiple attributes group decision-making based on the interval type-2 TOPSIS method. Expert Systems with Applications, 37(4), 2790-2798.

Deveci, M., Demirel, N. Ç., \& Ahmetoğlu, E. (2017). Airline new route selection based on interval type-2 fuzzy MCDM: A case study of new route between Turkey- North American region destinations. Journal of Air Transport Management, 59, 83-99.

Erdoğan, M., \& Kaya, İ., (2016). A combined fuzzy approach to determine the best region for a nuclear power plant in Turkey. Applied Soft Computing, 39, 84-93.

Ghadimi, P., Toosi, F. G., \& Heavey, C. (2018). A multi-agent systems approach for sustainable supplier selection and order allocation in a partnership supply chain. European Journal of Operational Research, 269, 286-301.

Govindan, K., Khodaverdi, R., \& Jafarian, A. (2013). A fuzzy multi criteria approach for measuring sustainability performance of a supplier based on triple bottom line approach. Journal of Cleaner Production, 47, 345-354.

Güner Gören, H. (2018). A decision framework for sustainable supplier selection and order allocation with lost sales. Journal of Cleaner Production, 183, 1156-1169

Hamdan, S., \& Cheaitou, A. (2017). Supplier selection and order allocation with green criteria: An MCDM and multiobjective optimization approach. Computers and Operations Research, 81, 282-304.

Hwang, C. L., \& Yoon, K. (1981). Multiple attribute decision making: Methods and applications. New York: SpringerVerlag.

Jolai, F., Yazdian, S. A., Shahanaghi, K., \& Khojasteh, M. A. (2011). Integrating fuzzy TOPSIS and multi-period goal programming for purchasing multiple products from multiple suppliers. Journal of Purchasing and Supply Management, 17(1), 42-53.

Kahraman, C., Öztayşi, B., Uçal Sarı, I., \& Turanoğlu, E. (2014). Fuzzy analytic hierarchy process with interval type-2 fuzzy sets. Knowledge-Based Systems, 59, 48-57.

Kannan, D. (2018). Role of multiple stakeholders and the critical success factor theory for the sustainable supplier selection process. International Journal of Production Economics, 195, 391-418.

Kannan, D., Jabbour, A. B. L. S., \& Jabbour, C. J. C. (2014). Selecting green suppliers based on GSCM practices: Using fuzzy TOPSIS applied to a Brazilian electronics company. European Journal of Operational Research, 233, 432447.

Khan, S. A., Kusi-Sarpong, S., Arhin, F. K., \& Kusi-Sarpong, H. (2018). Supplier sustainability performance evaluation and selection: A framework and methodology. Journal of Cleaner Production, 205, 964-979.

Küçük, O., \& Ecer, F. (2007). Bulanık TOPSIS kullanılarak tedarikçilerin değerlendirilmesi ve Erzurum'da bir uygulama. Bolu Abant Izzet Baysal Üniversitesi Iktisadi ve Idari Bilimler Fakültesi Ekonomik ve Sosyal Araştırmalar Dergisi, 3(1), 45-65.

Küçük, O., \& Ecer, F. (2008). Imalatçi işletmelerde uygun tedarikçi seçimi: Analitik hiyerarşi yöntemi ile bir KOBi uygulamasi. Atatürk Üniversitesi iktisadi ve Idari Bilimler Dergisi, 22(2), 435-450.

Kumar, D. T., Palaniappan, M., Kannan, D., \& Shankar, K. M. (2014). Analyzing the CSR issues behind the supplier selection process using ISM approach. Resources, Conservation and Recycling, 92, 268-278. 
Lin, H. F. (2010). An application of fuzzy AHP for evaluating course website quality. Computers \& Education, 54, 877888.

Luthra S., Govindan, K., Kannan D., Mangla, S. K., \& Garg, C. P. (2017). An integrated framework for sustainable supplier selection and evaluation in supply chains. Journal of Cleaner Production, 140: Part 3, 1686-1698.

Mahdiloo, M., Saen, R. F., \& Lee, K. H. (2015). Technical, environmental and eco-efficiency measurement for supplier selection: An extension and application of data envelopment analysis. International Journal of Production Economics, 168, 279-289.

Mendel, J. M., John, R. I. \& Liu, F. (2006). Interval type-2 fuzzy logic systems made simple. IEEE Transactions on Fuzzy Systems, 14(6), 808-821.

Nourmohamadi Shalke, P., Paydar, M. M., \& Hajiaghaei-Keshteli, M. (2018). Sustainable supplier selection and order allocation through quantity discounts. International Journal of Management Science and Engineering Management, 13, 20-32.

Önüt, S., Kara, S. S., \& Işik, E. (2009). Long term supplier selection using a combined fuzzy MCDM approach: A case study for a telecommunication company. Expert Systems with Applications, 36, 3887-3895.

Özdemir, A. I., \& Yalçın Seçme, N. (2009). İki aşamalı stratejik tedarikçi seçiminin bulanık TOPSıS yöntemi ile analizi. Afyon Kocatepe Üniversitesi i.i.B.F. Dergisi, 11(2), 79-112.

Reuter, C., Goebel, P., \& Foerstl, K. (2012). The impact of stakeholder orientation on sustainability and cost prevalence in supplier selection decisions. Journal of Purchasing and Supply Management, 18(4), 270-281.

Rodrigues Lima Junior, F., Osiro, L., \& Cesar Ribeiro Carpinetti, L. (2014). A comparison be tween fuzzy AHP and fuzzy TOPSIS methods to supplier selection. Applied Soft Computing, 21, 194-209.

Saaty, T. L. (1980). The analytic hierarchy process. New York: McGraw Hill Company.

Sarkis, J., \& Dhavale, D. G. (2015). Supplier selection for sustainable operations: A triple bottom- line approach using a Bayesian framework. International Journal of Production Economics, 166, 177-191.

Shaw, K., Shankar, R., Yadav, S. S., \& Thakur, L. S. (2012). Supplier selection using fuzzy AHP and fuzzy multi-objective linear programming for developing low carbon supply chain. Expert Systems with Applications, 39(9), 8182-8192.

Shen, L., Olfat, L., Govindan, K., Khodaverdi, R., \& Diabat, A. (2013). A fuzzy multi criteria approach for evaluating green supplier's performance in green supply chain with linguistic preferences. Resources, Conservation and Recycling, 74, 170-179.

Singh, A., Kumari, S., Malekpoor, H., \& Mishra, N. (2018). Big data cloud computing framework for low carbon supplier selection in the beef supply chain. Journal of Cleaner Production, 202, 139-149.

Song, W., Xu, Z., \& Liu, H. C. (2017). Developing sustainable supplier selection criteria for solar air-conditioner manufacturer: An integrated approach. Renewable and Sustainable Energy Reviews, 79, 1461-1471.

Thokala, P., \& Duenas, A. (2012). Multiple criteria decision analysis for health technology assessment. Value in Health, 15(8), 1172-1181.

Trapp, A. C., \& Sarkis, J. (2016). Identifying robust portfolios of suppliers: a sustainability selection and development perspective. Journal of Cleaner Production, 112, 2088-2100.

Vahidi, F., Torabi, S. A., \& Ramezankhani, M. J. (2018). Sustainable supplier selection and order allocation under operational and disruption risks. Journal of Cleaner Production, 174, 1351-1365.

Wang, J. W., Cheng, C. H., \& Huang K. C. (2009). Fuzzy hierarchical TOPSIS for supplier selection. Applied Soft Computing, 9(1), 377-386 .

Wang, X., \& Chan, H. K. (2013). A hierarchical fuzzy TOPSIS approach to assess improvement areas when implementing green supply chain initiatives. International Journal of Production Research, 51(10), 3117-3130.

Zadeh, L. A. (1975). The concept of a linguistic variable and its application to approximate reasoning -I. Information Sciences, 8, 199-249.

Zimmer, K., Fröhling, M., \& Schultmann, F. (2015). Sustainable supplier management: A review of models supporting sustainable supplier selection, monitoring and development. International Journal of Production Research, 54(5), 1412-1442. 
This Page Intentionally Left Blank 